\title{
Chemia i katalizatory procesu głębokiego hydroodsiarczania
}

\begin{abstract}
W artykule przedstawiono zagadnienia związane ze zrozumieniem mechanizmu katalitycznego procesu głębokiego hydroodsiarczania (HDS). Omówiono rodzaje związków siarki występujących w surowcach naftowych oraz ich reaktywność w aspekcie drugiego stopnia hydrorafinacji. Opisano typy katalizatorów procesu HDS oraz przedstawiono zagadnienia związane z wykorzystaniem nowych katalizatorów (niesiarczkowych) mających potencjalne zastosowanie w drugim (głębokim) stopniu hydrorafinacji.
\end{abstract}

Słowa kluczowe: hydroodsiarczanie (HDS), hydrorafinacja, reaktywność związków siarki, karbazol, dibenzotiofen (DBT), 4,6-dimetylodibenzotiofen (4,6-DMDBT).

\section{Chemistry and catalysts of deep hydrodesulfurization process}

The paper presents issues related to the understanding of the catalytic mechanism of the deep hydrodesulphurization process (HDS). The types of sulfur compounds present in petroleum products and their reactivity in terms of the second degree of hydrotreatment are discussed. The types of catalysts for the HDS process were described and the issues related to the use of new (non-sulfide) catalysts which have potential application in the second (deep) hydrotreatment are presented.

Key words: hydrodesulfurization (HDS), hydrotreating, reactivity of sulphur compounds, carbazole, dibenzothiophene (DBT), 4,6-dimethyldibenzothiophene (4,6-DMDBT).

\section{Wstęp}

Zaostrzanie przepisów dotyczących ochrony środowiska i związane $\mathrm{z}$ tym coraz bardziej restrykcyjne ograniczanie zawartości siarki (emisja $\mathrm{SO}_{2}$ ) w produkowanych paliwach zmusza przemysł rafineryjny do systematycznego usprawnienia procesów hydroodsiarczania, stosowanych od prze- szło sześćdziesięciu lat. W 2009 roku dopuszczalna zawartość siarki dla olejów napędowych została obniżona z 50 ppm do 10 ppm $[12,38]$. W przyszłości przewiduje się wprowadzenie dopuszczalnego poziomu siarki poniżej 1 ppm wagowego $[1,27,30]$.

\section{Typy heterocyklicznych związków siarki występujących w surowcach naftowych}

Siarka w ropie naftowej występuje w postaci merkaptanów, siarczków i disiarczków (w lekkich frakcjach naftowych) jako tiofeny, benzotiofeny, dibenzotiofeny $i$ ich alkilowe pochodne oraz w postaci związków z większą liczbą pierścieni aromatycznych [11, 28, 35] w wyżej wrzących frakcjach. Największą zawartość siarki w wysoko wrzących frakcjach stanowią związki zawierające dwa pierścienie aromatyczne - głównie pochodne dibenzotiofenu (DBT), którego strukturę wraz z numeracją atomów węgla przedstawiono na rysunku 1.

Przykładowe struktury związków siarki przedstawiono na rysunku 2.

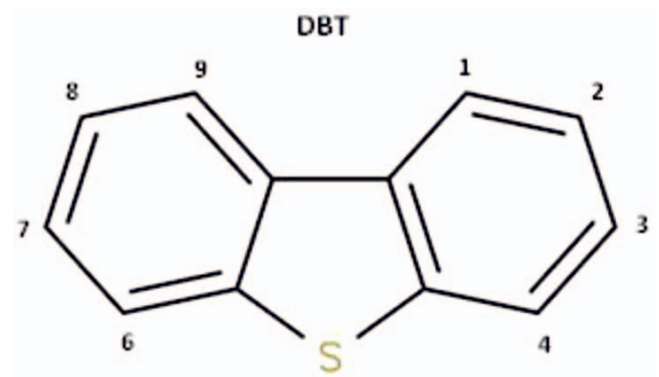

Rys. 1. Struktura i numeracja atomów węgla w cząsteczce dibenzotiofenu (DBT) 


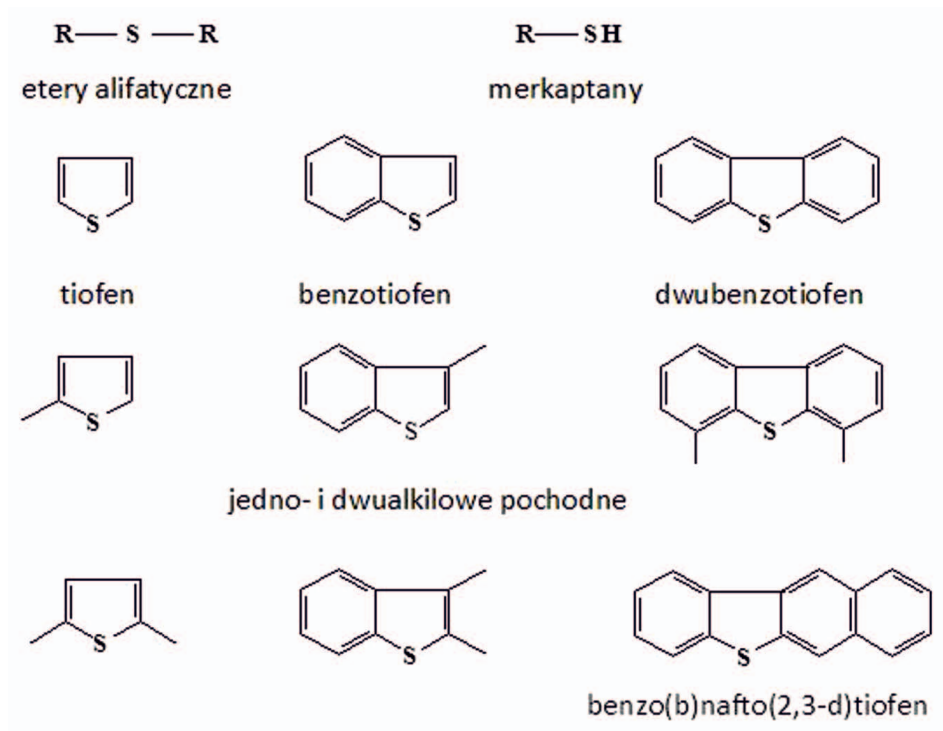

Rys. 2. Związki siarki występujące w frakcjach ropy naftowej

Szczegółowe badania analityczne pozwoliły na identyfikację więcej niż jedno- czy dwualkilowych pochodnych DBT, takich jak np. 3,4,6-trimetylo-8-etylodibenzotiofen [23]. Ponadto większość pochodnych DBT zindefikowano jako etylowe, izopropylowe czy też izobutylowe pochodne głównie w pozycjach 4 i 6 [36]. Z dostępnych danych literaturowych [31] wynika, że związki siarki obecne w surowych olejach dieslowskich można podzielić zasadniczo na dwie grupy. Pierwszą grupę stanowią pochodne alkilowe benzotiofenu (BT) zawierające
$1 \div 7$ atomów węgla w podstawnikach, a drugą pochodne DBT posiadające $1 \div 5$ atomów węgla jako podstawniki. Alkilowe pochodne BT gromadzą się głównie w frakcjach wrzących poniżej $300^{\circ} \mathrm{C}$, a pochodne DBT $-w$ frakcjach wrzących powyżej $300^{\circ} \mathrm{C}$. Frakcje o zakresie wrzenia $300 \div 340^{\circ} \mathrm{C}$ zawierają wysokie stężenia $\mathrm{C}_{1} \mathrm{i} \mathrm{C}_{2}$ pochodnych DBT razem z $\mathrm{C}_{5} \mathrm{i}_{6}$ - pochodnymi BT [31]. Konwencjonalnym procesom hydrorafinacji poddawane są frakcje destylacyjne posiadające od 1 do $2 \%$ siarki. Biorąc pod uwagę warunki prowadzenia procesu (temperatura, ciśnienie wodoru, czas kontaktu), związki siarki podzielono na dwie grupy: pierwsza to tzw. „siarka łatwa” (usuwana w łagodnych warunkach procesu), zawierająca związki niearomatyczne siarki (merkaptany, siarczki, disiarczki), tiofen i jego pochodne, benzotiofen i jego pochodne; druga to tzw. „siarka trudna" $(0,2 \div 0,3 \%)$ (jej usunięcie wymaga ostrzejszych warunków) wciąż obecna w dieslowskich frakcjach po konwencjonalnym procesie HDS, którą stanowią różnego rodzaju głównie alkilowe pochodne DBT, szczególnie te zawierające podstawniki alkilowe w pozycjach 4 i 6 [36]. Z punktu widzenia badań aktywności katalizatorów w aspekcie głębokiej hydrorafinacji autorzy prac skupiają się głównie na analizie HDS 4,6-DMDBT - jako modelowego najbardziej reprezentatywnego przedstawiciela słabo reaktywnych w procesie HDS związków siarki.

\section{Reaktywność związków siarki - przeszkody steryczne}

Reaktywność cyklicznych związków siarki maleje wraz ze wzrostem liczby pierścieni w cząsteczce: tiofeny $>$ benzotiofeny $>$ dibenzotiofeny $>$ alkilowe pochodne dibenzotiofenu. Zawartość tych ostatnich we frakcjach olejowych ogranicza możliwość obniżenia koncentracji siarki w tych paliwach do wymaganego poziomu. Usunięcie niereaktywnych w procesach alkilowych pochodnych dibenzotiofenu wymaga jednak istotnej zmiany warunków prowadzenia procesu, jak również zmiany właściwości stosowanych katalizatorów [5, 6]. Proces głębokiego hydroodsiarczania polega na usuwaniu siarki głównie z poliaromatycznych związków typu dibenzotiofenu (DBT) i jego alkilowych pochodnych, niereaktywnych, a zatem nieusuwalnych w warunkach konwencjonalnych [6], czyli w pierwszym stopniu hydrorafinacji.

Katalityczne hydroodsiarczanie 4,6-DMDBT (po utworzeniu pośredniej zaadsorbowanej dwuwodoropochodnej) może przebiegać poprzez bezpośrednią hydrogenolizę wiązania C-S, prowadzącą do powstania 3,3'-dimetylobifenylu lub przez uwodornienie jednego z pierścieni benzenowych, a następnie hydrogenolizę wiązania $\mathrm{C}-\mathrm{S} \mathrm{w}$ produkcie pośrednim prowadzącą do utworzenia 3-(3'-metylocykloheksylo) toluenu. Przebieg reakcji hydroodsiarczania 4,6-DMDBT przedstawiono na rysunku 3.

Do niedawna uważano, że powodem niskiej reaktywności 4,6-DMDBT jest niski stopień adsorpcji cząsteczki związku na centrach aktywnych katalizatora. Wyniki badań wykazały, że ciepła adsorpcji DBT oraz 4,6-DMDBT na powierzchni katalizatora $\mathrm{NiMo} / \mathrm{Al}_{2} \mathrm{O}_{3}$ są porównywalne i wynoszą odpowiednio: $11 \mathrm{kcal} / \mathrm{mol}$ i $15 \mathrm{kcal} / \mathrm{mol}$ [13]. Inne wyniki badań [36] dowiodły, że stałe równowagi adsorpcji DBT, 2,8-DMDBT i 4,6-DMDBT są praktycznie takie same, pomimo różnicy reaktywności tych związków. Powyższe wyniki sugerują, że badane związki prawdopodobnie adsorbują się przez $\pi$ elektrony układu aromatycznego. A zatem różnice w reaktywności nie mogą być tlumaczone czynnikami związanymi $\mathrm{z}$ adsorpcją na powierzchni katalizatora. Biorąc pod uwagę otrzymane rezultaty, należy stwierdzić, że niemożliwa jest adsorpcja poprzez bezpośrednie oddziaływanie atomu siarki dla alkilowych pochodnych DBT, a zatem dominuje adsorpcja płaska. Niższa reaktywność 4-MDBT i 4,6-DMDBT jest thumaczona przeszkodami przestrzennymi spowodowanymi obecnością grup metylowych w pozycjach 4 i 6 . 


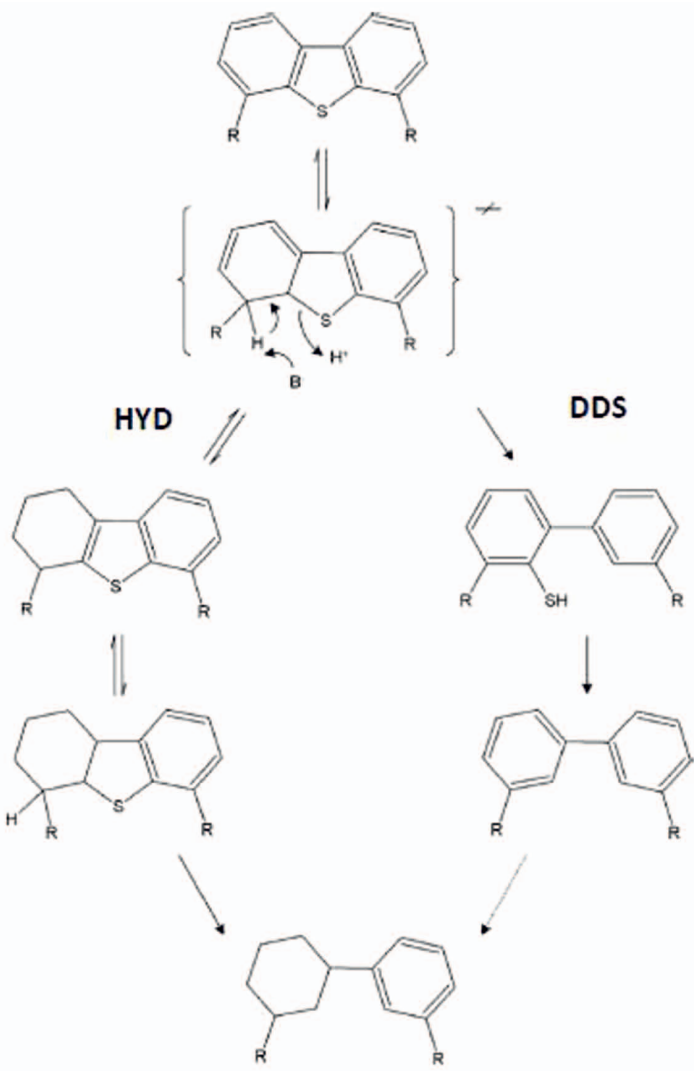

Rys. 3. Ogólny schemat przemian 4,6-DMDBT;

DDS - ścieżka bezpośredniego odsiarczania,

HYD - ścieżka poprzez uwodornienie; $\mathrm{R}$ - grupa $\mathrm{CH}_{3}[4]$

Z drugiej strony wyższa reaktywność 2,8-DMDBT wyjaśniana jest łatwiejszym i szybszym tworzeniem się częściowo uwodornionych związków pośrednich spowodowanych donorowym efektem grup metylowych - podstawniki alkilowe zwiększają gęstość elektronową pierścienia aromatycznego $[31,36]$. Zostało to przedstawione w tablicy 1 i na rysunku 4. Dane w tablicy 1 pokazują względną reaktywność pochodnych DBT, co ewidentnie wskazuje, że położenie podstawników alkilowych $\mathrm{w}$ pierścieniach aromatycznych $\mathrm{w}$ istotny sposób wpływa na reaktywność cząsteczki związku.

Tablica 1. Względna reaktywność pochodnych alkilowych DBT [5]

\begin{tabular}{|l|c|c|c|}
\hline Położenie podstawnika & DBT & 4-MDBT & 4,6-DMDBT \\
\hline Aktywność względna & 1,00 & 0,43 & 0,17 \\
\hline Położenie podstawnika & DBT & 2-MDBT & 2,8-DMDBT \\
\hline Aktywność względna & 1,00 & 1,50 & 1,97 \\
\hline
\end{tabular}

Zarówno DBT, jak i 4,6-DMDBT mogą adsorbować się na powierzchni katalizatora poprzez adsorpcję płaską lub z wykorzystaniem adsorpcji poprzez atom siarki. Różnica wynika z małego stopnia adsorpcji koordynacyjnej poprzez heteroatom siarki. Uniemożliwiona adsorpcja alkilowych pochodnych DBT związku na centrum aktywnym poprzez hetero-

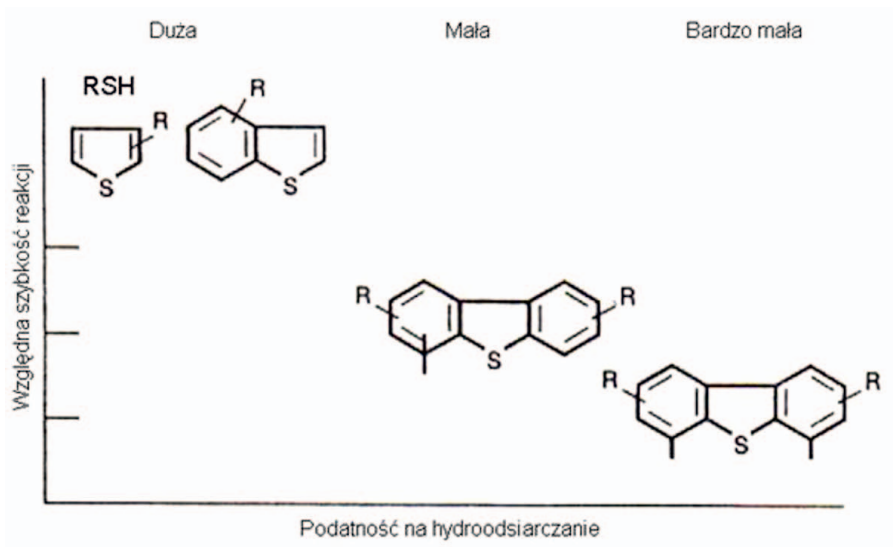

Rys. 4. Klasyfikacja związków siarki ze względu na ich reaktywność w procesie hydroodsiarczania [14]

atom $\mathrm{S}$ powoduje zatem, że mechanizm przemian chemicznych tego typu związków (alkilowych pochodnych DBT) zachodzi na drodze uwodornienia. Pozwala to na zmianę konformacji częściowo uwodornionej cząsteczki 4,6-DMDBT, zwiększając $w$ ten sposób dostęp do heteroatomu i umożliwiając dzięki temu łatwą ekstrakcję atomu siarki z tak otrzymanej wodoropochodnej cząsteczki związku siarki - rysunek 5 [7].

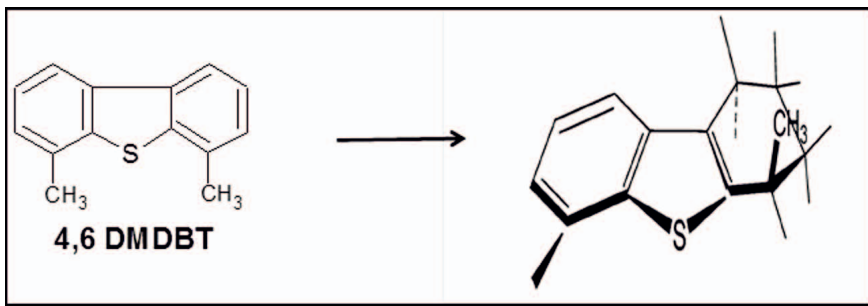

Rys. 5. Zmiana konformacji 4,6-DMDBT (płaska) po uwodornieniu do 4,6-dimetylotetrahydrodibenzotiofenu [7]

Istotną rolę $\mathrm{w}$ tym procesie odgrywają etylowe, izopropylowe i izobutylowe pochodne DBT. Wielkość samego podstawnika (w pozycji 4,6 ) również wpływa na ich reaktywność - wzrost długości łańcucha zmniejsza reaktywność związku, pomimo jednakowej adsorpcji na centrach aktywnych katalizatora - poprzez elektrony $\pi$ jednego z pierścieni aromatycznych [25].

Jak wspomniano, długość podstawnika alkilowego w pozycjach 4 oraz 4 i 6 może decydować o reaktywności takiej cząsteczki, w związku z tym na przykład 4,6-dipropylodibenzotiofen jest siedmiokrotnie mniej reaktywny niż cząsteczka 4,6-DMDBT. A zatem alkilowa pochodna DBT ulega jedynie procesowi odsiarczania na drodze uwodornienia. Wobec tego dla niepodstawionego DBT bardziej uprzywilejowana jest droga bezpośredniego odsiarczenia (DDS), natomiast dla alkilowych pochodnych DBT zjawisko to zachodzi w procesie poprzez uwodornienie (HYD).

Mijoin i współpracownicy [24] wykazali, że czynnikami wpływającymi na kierunek reakcji (ścieżka DDS versus 
ścieżka HYD), jak i na aktywność katalizatorów siarczkowych są:

- zasadowość anionowa sąsiadujących wakancji i kwasowość grup SH powstałych w wyniku heterolitycznego rozpadu $\mathrm{H}_{2}$ na parze centrów wakancja-anion siarki,

- dostępność i reaktywność wodoru związanego z centrami katalitycznymi,

- przeszkody przestrzenne występujące w cząsteczce związku siarki.

Również istotnym faktem koniecznym do uwzględnienia w badaniach przemian alkilopochodnych jest obecność w surowcu węglowodorów poliaromatycznych i związków azotu, które wykazują konkurencyjną adsorpcję na centrach aktywnych katalizatora. W rzeczywistości proces hydroodsiarczania nie przebiega samodzielnie. Towarzyszą mu zachodzące równolegle reakcje hydroodazotowania (HDN) i hydroodtlenienia (HDO) związków azotu i tlenu obecnych w surowcu. Ponadto zachodzą reakcje uwodornienia. Związki azotu wpływają inhibitująco na proces HDS [10]. Inhibitują one silniej proces uwodornienia niż bezpośredniego odsiarczenia (DDS) DBT.

Podobne zjawiska zaobserwowano dla 4,6-DMDBT [16], z tym, że inhibitujący efekt związków azotu jest silniejszy. Wiąże się to z faktem, że hydroodsiarczanie alkilowych pochodnych DBT (zachodzące głównie przez uwodornienie) i hydroodazotowanie związków azotu (zachodzące również głównie przez uwodornienie) mają miejsce na tych samych centrach aktywnych katalizatora [39]. Ten sam wpływ wykazują węglowodory poliaromatyczne, inhibitując uwodornienie 4,6-DMDBT [15].

Przedstawiony szczegółowo proces HDS alkilowych pochodnych DBT wskazuje wyraźnie na istniejące różnice w reaktywności pomiędzy DBT a jego alkilowymi pochodnymi w warunkach konwencjonalnego procesu HDS.

W chwili obecnej, w odniesieniu do procesu głębokiej hydrorafinacji, najdokładniej przebadaną grupę katalizatorów stanowią siarczkowe katalizatory $\mathrm{Co}(\mathrm{Ni})-\mathrm{Mo}(\mathrm{W})$ osadzone na różnego typu nośnikach, takich jak: tlenek glinu, mieszanina zeolitów z tlenkiem glinowym oraz inne nośniki dwuskładnikowe, zeolity i związki mezoporowate, a także węgle aktywne. Dotychczasowe wysiłki zmierzały głównie do zmiany kwasowości układu katalitycznego - wpływającej na migrację grup alkilowych z pozycji 4 i 6 w inne lub ich dealkilację, eliminując w ten sposób efekt przeszkód przestrzennych. Jednakże w dalszym ciągu fazą aktywną jest faza siarczkowa CoMoS, NiMoS czy Co(Ni)WS.

Ogólną klasyfikację katalizatorów, przedstawioną powyżej w aspekcie głębokiego hydroodsiarczenia 4,6-dimetylodibenzotiofenu (4,6-DMDBT) jako związku modelowego, zaprezentowano na podstawie danych literaturowych na rysunku 6 [2]

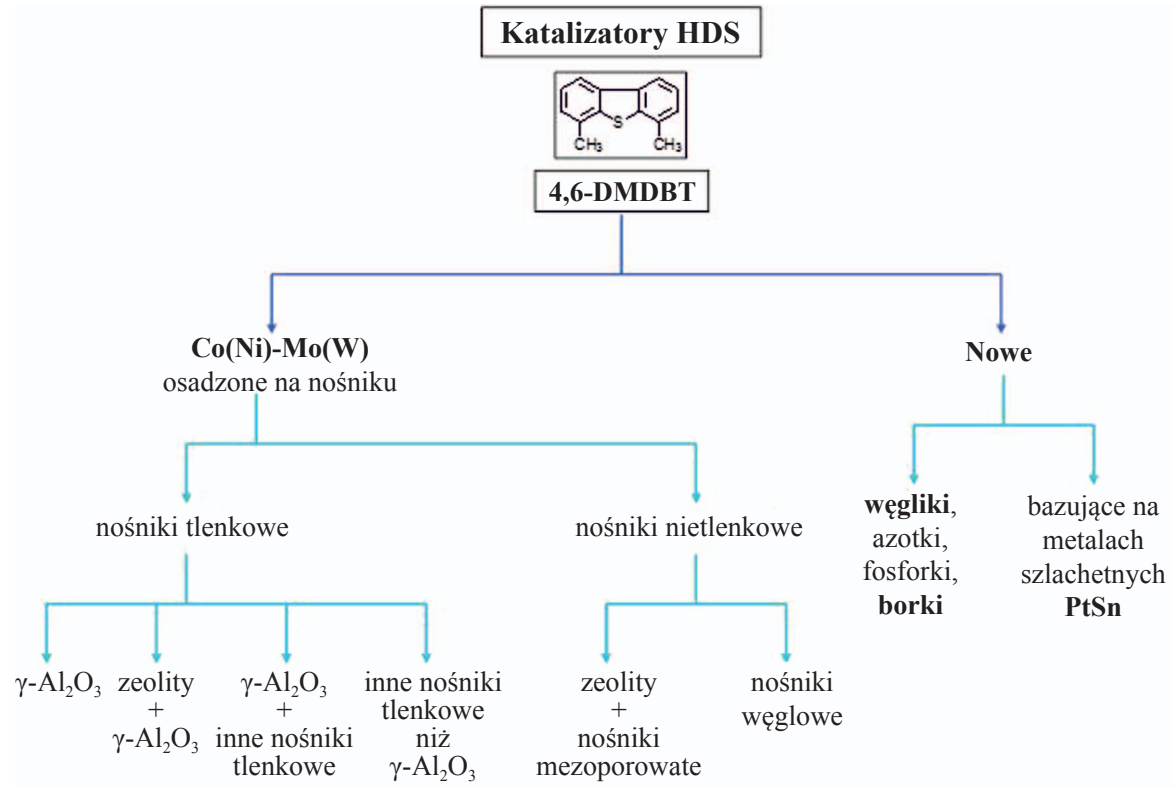

Rys. 6. Klasyfikacja stosowanych katalizatorów w procesie głębokiej hydrorafinacji

Przedstawione powyżej aspekty związane z trudnościami hydrorafinacji alkilowych pochodnych DBT zmuszają do poszukiwania nowych katalizatorów o aktywności pozwalającej na zrealizowanie procesu z zadowalającym rezultatem. Omówione problemy powodują konieczność poszukiwania nowych materiałów katalitycznych, nośnika i fazy aktywnej, które w przyszłości mogłyby się stać materiałami wyjściowymi do otrzymania i syntezy nowych, bardziej aktywnych katalizatorów hydrorafinacji. Istnieje duża grupa materiałów będących potencjalnymi niesiarczkowymi katalizatorami głębokiej hydrorafinacji, do której należą: węgliki [9, 19, 21, 22, 32-34], fosforki [8, 26, 29, 37] oraz ostatnio również borki metali przejściowych $[17,18]$. Materiały te to tzw. , ceramika beztlenowa” oraz katalizatory oparte na metalach szlachetnych, np. układy bimetaliczne PtSn [20]. Poszukiwania i wybór do badań nowych układów katalitycznych podyktowany był dwiema przesłankami, a mianowicie:

- ich wysoką aktywnością uwodorniającą, która jest wskazana w reakcjach głębokiej hydrorafinacji,

- ich odpornością na zatrucie siarką powodującą zazwyczaj dezaktywację klasycznych katalizatorów w reakcji uwodornienia. 


\section{Podsumowanie}

Niesiarczkowe katalizatory - węgliki molibdenu i wolframu, borek niklu i katalizatory PtSn, stanowiące obiekt intensywnych badań, charakteryzują się dobrymi właściwościami hydrorafinacyjnymi w reakcjach HDS i HDN. Przeprowadzone w badaniach reakcje wykazały, że mechanizm przemian takich związków siarki jak DBT, 4,6-DMDBT i karbazolu jest praktycznie taki sam. Kierunki zachodzących przemian obu reakcji były takie same jak na katalizatorach siarczkowych, jednakże z większą wydajnością produktów hydroodsiarczania czy hydroodazotowania. Wzmocnienie właściwości metalicznych odpowiedzialnych za uwodornienie, jak i hydrogenolizę wiązań C-N i C-S wydaje się być właściwym kierunkiem rozwoju katalizatorów II stopnia hydrorafinacji - deep HDS.
Prowadzone badania wykazały znaczącą odporność badanych układów katalitycznych na obecność siarki, jak również możliwość zastosowania ich jako „składników fazy aktywnej” nowych układów katalitycznych II stopnia hydrorafinacji. Zatem opracowanie katalizatorów o silnych właściwościach metalicznych (uwodorniających), a jednocześnie odpornych na obecność siarki (co zostało pokazane w cytowanych pracach [9, 17-22, 32-34]) wydaje się być właściwym kierunkiem rozwoju niesiarczkowych katalizatorów II stopnia hydrorafinacji, jak również katalizatorów reakcji uwodornienia, celem eliminacji siarki. W przyszłości badania nowych katalizatorów będą zintensyfikowane w kierunku procesu hydroodtlenienia (HDO), szczególnie pod kątem hydrorafinacji biopaliw [3].

Prosimy cytować jako: Nafta-Gaz 2017, nr 9, s. 685-690, DOI: 10.18668/NG.2017.09.08

Artykuł nadesłano do Redakcji 28.06.2017 r. Zatwierdzono do druku 02.08.2017 r.

\section{Literatura}

[1] Alsolami B., Carneiro J.T., Moulijn J.A., Makkee M.: On-site low-pressure diesel HDS for fuel cell applications: Deepening the sulfur content to $<1 \mathrm{ppm}$. Fuel 2011, vol. 90, nr 10, s. 3021-3027.

[2] Bej S.K., Maity S.K., Turaga U.T.: Search for an Efficient 4,6-DMDBT Hydrodesulfurization Catalyst: A Review of Recent Studies. Energy \& Fuels 2004, vol. 18, nr 5, s. 1227-1237.

[3] Boullosa-Eiras S., Lødeng R., Bergem H., Stocker M., Hannevold L., Blekkan E.A.: Catalytic hydrodeoxygenation (HDO) of phenol over supported molybdenum carbide, nitride, phosphide and oxide catalysts. Catalysis Today 2014 vol. 223, s. 44-53.

[4] Breysse M., Djega-Mariadassou G., Pessayre S., Geantet C., Vrinat M., Pérot G., Lemaire M.: Deep desulfurization: reactions, catalysts and technological challenges. Catalysis Today 2003, vol. 84, nr 3-4, s. 129-138.

[5] Czachowska-Kozłowska D., Lewandowski M.: Transformations of dibenzothiophene and alkyldibenzothiophenes in advanced hydrodesulfurization processes. Przemysł Chemiczny 2003, vol. 82, nr 12, s. 1484-1490.

[6] Czachowska-Kozłowska D., Lewandowski M.: New processes for deep hydrodesulfurization of diesel fuels. Przemysł Chemiczny 2002, vol. 81, nr 9, s. 577-582.

[7] Egorova M., Prins R.: Competitive hydrodesulfurization of 4,6-dimethyldibenzothiophene, hydrodenitrogenation of 2-methylpyridine, and hydrogenation of naphthalene over sulfided $\mathrm{NiMo} / \gamma-\mathrm{Al}_{2} \mathrm{O}_{3}$. Journal of Catalysis 2004, vol. 224, nr 2, s. 278-287.

[8] Fang M., Tang W., Yu Ch., Xia L., Xia Z., Wang Q., Luo Z.: Performance of Ni-rich bimetallic phosphides on simultaneous quinoline hydrodenitrogenation and dibenzothiophene hydrodesulfurization. Fuel Processing Technology 2015, vol. 129, s. 236-244.

[9] Furimsky E.: Metal carbides and nitrides as potential catalysts for hydroprocessing. Applied Catalysis A: General 2003, vol. 240 , nr 1-2, s. 1-28.
[10] Gates B.C., Topsoe H.: Reactivities in deep catalytic hydrodesulfurization: challenges, opportunities, and the importance of 4-methyldibenzothiophene and 4,6-dimethyldibenzothiophene. Polyhedron 1997, vol. 16, nr 18, s. 3213-3217.

[11] Girgis M.J., Gates B.C.: Reactivities, reaction networks, and kinetics in high-pressure catalytic hydroprocessing. Industrial \& Engineering Chemistry Research 1991, vol. 30, nr 9, s. 2021-2058.

[12] Hynaux A., Sayag C., Suppan S., Trawczyński J., Lewandowski M., Szymańska-Kolasa A., Djega-Mariadassou G.: Kinetic study of the hydrodesulfurization of dibenzothiophene over molybdenum carbides supported on functionalized carbon black composite: Influence of indole. Applied Catalysis B: Enviromental 2007, vol. 72, nr 1-2, s. 62-70.

[13] Kabe T., Aoyama Y., Wang D., Ishihara A., Qian W., Hosoya M., Zhang Q.: Effects of $\mathrm{H}_{2} \mathrm{~S}$ on hydrodesulfurization of dibenzothiophene and 4,6-dimethyldibenzothiophene on alumina-supported NiMo and NiW catalysts. Applied Catalysis 2001, vol. 209, nr 1-2, s. 237-247.

[14] Kim G., Knudsen B., Cooper H., Topsøe H.: Catalyst and process technologies for ultra low sulfur diesel. Applied Catalysis 1999, vol. 189, nr 2, s. 205-215.

[15] Koltai T., Macaud M., Guevara A., Schulz E., Lemaire M., Bacaud R., Vrinat M.: Comparative inhibiting effect of polycondensed aromatics and nitrogen compounds on the hydrodesulfurization of alkyldibenzothiophenes. Applied Catalysis A: General 2002, vol. 231, nr 1-2, s. 253-261.

[16] Kwark Ch., Lee J.J., Bae J.S., Moon S.H.: Poisoning effect of nitrogen compounds on the performance of CoMoS/ $\mathrm{Al}_{2} \mathrm{O}_{3}$ catalyst in the hydrodesulfurization of dibenzothiophene, 4-methyldibenzothiophene, and 4,6-dimethyldibenzothiophene. Applied Catalysis B: Enviromental 2001, vol. 35, nr 1, s. $59-68$

[17] Lewandowski M.: Hydrotreating activity of bulk NiB alloy in model reaction of hydrodrodenitrogenation of carbazole. Applied Catalysis B: Environmental 2015, vol. 168, s. 322-332. 
[18] Lewandowski M.: Hydrotreating activity of bulk NiB alloy in model reaction of hydrodesulfurization 4,6-dimethyldibenzothiophene. Applied Catalysis B: Environmental 2014, vol. 160-161, s. 10-21.

[19] Lewandowski M., Da Costa P., Benichou D., Sayag C.: Catalytic performance of platinum doped tungsten carbide in simultaneous hydrodenitrogenation and hydrodesulphurization. Applied Catalysis B: Environmental 2010, vol. 93, nr 3-4, s. 241-249.

[20] Lewandowski M., Sarbak Z.: Simultaneous HDS and HDN over supported PtSn catalysts in comparison to commercial NiMo/ $\mathrm{Al}_{2} \mathrm{O}_{3}$. Applied Catalysis B: Environmental 2008, vol. 79, nr 4, s. 313-322.

[21] Lewandowski M., Szymańska-Kolasa A., Da Costa P., Sayag C.: Catalytic performances of platinum doped molybdenum carbide for simultaneous hydrodenitrogenation and hydrodesulfurization. Catalysis Today 2007, vol. 119, nr 1-4, s. 31-34.

[22] Lewandowski M., Szymańska-Kolasa A., Sayag C., Beaunier P., Djega-Mariadassou G.: Atomic level characterization and sulfur resistance of unsupport $W_{2} C$ during dibenzothiophene hydrodesulfurization. Classical kinetics simulation of the reaction. Applied Catalysis B: Environmental 2014, vol. 144, s. $750-759$

[23] Lorentz C., Laurenti D., Zotin J.L., Geantet C.: Comprehensive $G C \times G C$ chromatography for the characterization of sulfur compound in fuels: A review. Catalysis Today 2017, vol. 292, s. 26-37.

[24] Mijoin J., Perot G., Bataille F., Lemberton J.L., Breysse M., Kasztetan S.: Mechanistic considerations on the involvement of dihydrointermediates in the hydrodesulfurization of dibenzothiophene-type compounds over molybdenum sulfide catalysts. Catalysis Letters 2001, vol. 71, nr 3-4, s. 139-145.

[25] Milenkovic A., Macaud M., Schulz E., Koltai T., Loffeda D., Vrinat M., Lemaire M.R.: How could organic synthesis help the understanding of the problems of deep hydrodesulfurization of gasoils? Compte Rendus de l'Academie des Sciences - Series II C Chemistry 2000, vol. 3, nr 6, s. 459-463.

[26] Oyama S.T., Lee Y-K.: The active site of nickel phosphide catalysts for the hydrodesulfurization of 4,6-DMDBT. Journal of Catalysis 2008, vol. 258, nr 2, s. 393-400.

[27] Pawelec B., Nawarro R.M., Campos-Martin J., Fierro J.L.G.: Towards near zero-sulfur liquid fuels: a perspective review. Catalysis Science and Technology 2011, vol. 1, s. 23-42.

[28] Shafi R., Hutchings G.J.: Hydrodesulfurization of hindered dibenzothiophenes: an overview. Catalysis Today 2000, vol. 59, nr 3-4, s. 423-442.

[29] Shu Y., Lee Y-K., Oyama S.T.: Structure-sensitivity of hydrodesulfurization of 4,6-dimethyldibenzothiophene over silica-supported nickel phosphide catalysts. Journal of Catalysis 2005, vol. 236, nr 1, s. 112-121.
[30] Song C.: An overview of new approaches to deep desulfurization for ultra-clean gasoline, diesel fuel and jet fuel. Catalysis Today 2003, vol. 86, nr 1-4, s. 211-263.

[31] Stanislaus A., Marafi A., Rana M.S.: Recent advances in the science and technology of ultra low sulfur diesel (ULSD) production. Catalysis Today 2010, vol. 153, nr 1-2, s. 1-68.

[32] Szymańska A., Lewandowski M., Sayag C., Djéga-Mariadassou G.: Kinetic study of the hydrodenitrogenation of carbazole over bulk molybdenum carbide. Journal of Catalysis 2003, vol. 218, nr 1, s. 24-31.

[33] Szymańska-Kolasa A., Lewandowski M., Sayag C., Brodzki D., Djéga-Mariadassou G.: Comparison between tungsten carbide and molybdenum carbide for the hydrodenitrogenation of carbazole. Catalysis Today 2007, vol. 119, nr 1-4, s. 35-38.

[34] Szymańska-Kolasa A., Lewandowski M., Sayag C., DjégaMariadassou G.: Comparison of molybdenum carbide and tungsten carbide for the hydrodesulfurization of dibenzothiophene. Catalysis Today 2007, vol. 119, nr 1-4, s. 7-12.

[35] Topsoe H., Clause B.S., Massoth F.E.: Hydrotreating Catalysis. Springer, Berlin 1996.

[36] Vrinat M., Laurenti D., Geantet Ch.: Use of competitive kinetics for the understanding of deep hydrodesulfurization and sulfide catalysts behawior. Applied Catalysis B: Enviromental 2012, vol. 128, s. 3-9.

[37] Yang L., Li X., Wang A., Prins R., Chen Y., Duan X.: Hydrodesulfurization of dibenzothiophene, 4,6-dimethyldibenzothiophene, and their hydrogenated intermediates over bulk tungsten phosphide. Journal of Catalysis 2015, vol. 330, s. 330-343.

[38] Zepeda T.A., Pawelec B., Fierro J.L.G., Halachev T.: Removal of refractory S-containing compounds from liquid fuels on novel bifunctional CoMo/HMS catalysts modified with Ti. Applied. Catalysis B: Environmental 2007, vol. 71, nr 3-4, s. 223-236.

[39] Zeuthen P., Knudsen K.G., Whitehurst D.D.: Organic nitrogen compounds in gas oil blends, their hydrotreated products and the importance to hydrotreatment. Catalysis Today 2001, vol. 65 , nr 2-4, s. 307-314.

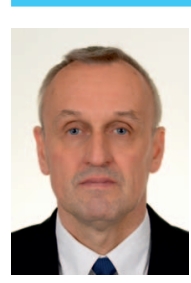

Dr hab. inż. Marek LEWANDOWSKI Adiunkt w Katedrze Technologii Paliw Wydział Energetyki Paliw. Akademia Górniczo-Hutnicza al. A. Mickiewicza 30

30-059 Kraków

E-mail:lewandowski@agh.edu.pl 